\title{
How Archbishop Spottiswoode Became an Episcopalian
}

\author{
JULIAN GOODARE
}

University of Edinburgh

L'archevêque John Spottiswoode (1565-1639) était le plus éminent épiscopalien d'Écosse. Toutefois, au début de sa carrière il était fermement presbytérien. Cette étude montre quand et comment ce changement s'est opéré. L'événement au cour de ce changement est une tentative de « coup d'état » organisée par le mouvement presbytérien du 17 au 19 décembre 1596. L'étude montre également que l'archevêque Spottiswoode a participé à cette opération, et explique que son ouvrage History est la seule source de certains de ces événements. Après l'échec du « coup », Spottiswoode a d'abord pris une position dangereusement radicale. Désavoué ensuite par les dirigeants presbytériens, il a, comme beaucoup d'autres, joint la position érastienne, qu'il a conservéle reste de sa carrière.

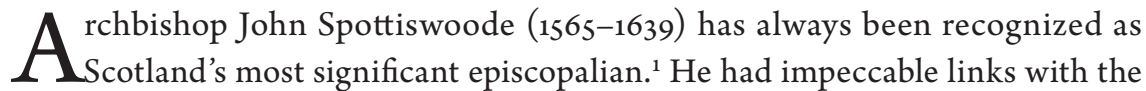
Reformation, as the son of one of the "six Johns" who drafted the First Book of Discipline (1560-61). He collaborated with and succeeded his father as minister of Calder before becoming archbishop of Glasgow (1603) and of St Andrews (1615). As archbishop he was the linchpin of James vi's episcopalian programme in the early seventeenth century. The Spottiswoode Society was founded in 1843, and between then and 1856 published several influential episcopalian texts, including the three volumes of its eponym's History of the Church of Scotland. ${ }^{2}$

Episcopacy in Spottiswoode's day was controversial — and Spottiswoode himself in his early career was strongly against it. In the early years of the Reformation, the Protestant church's polity was unsettled; policy was made at the national level by the general assembly, but who should manage the church at the crucial regional level? In the 1560 os there were a few bishops, five superintendents (including Spottiswoode's father), and many temporary commissioners. Some ministers began to argue in the 1570 s that hierarchy was unscriptural and that the church should be governed solely by committees of parish ministers-especially the famous "presbyteries." This led to periodic conflict when the government tried to promote bishops who were more under its control. When James vi began his personal rule in the $1580 \mathrm{os}$, he saw himself as a godly prince who should in some sense govern the church, but did not initially 
commit himself to episcopacy, and the presbyterians had a good deal of success up to the early 1590 . However, from 1596 onwards the political tide turned against them, as a result of events that will be at the centre of this article. ${ }^{3}$

Wayne Pearce has indicated how difficult it is to explain, or even date, Spottiswoode's conversion to the episcopalian cause:

The available evidence, although inconclusive, tends to indicate that Spottiswoode was indeed an adherent of the more zealous presbyterian party within the church up until the turn of the century[...]. Proceeding on the assumption that he was a firm believer in the ecclesiology adumbrated in the Second Book of Discipline, the answer to his conversion to erastian episcopacy lies in the years between 1596 and 1600.4

The period 1596-1600 was a crucial, varied, and eventful one, and it would be desirable to be more specific. This article draws on a wider range of evidence in order to achieve this. It argues that Spottiswoode's conversion to what became the episcopalian cause took place in the winter of 1596-97, when he was minister of Calder (now Mid Calder), in the presbytery of Linlithgow. It is a case-study of the changing of a mind.

The changing of Spottiswoode's mind is of interest in itself, since he had such an influential role. As a case-study, though, it is also of wider interest. Scotland at the time of the Reformation was often an unstable place, with competing pressures from different political factions and different religions. Other countries, notably England but also France and Spain, meddled in Scottish affairs for their own interests. There were uprisings, coups, and revolutions. In response, many people came to desire a strong monarchy as a bulwark against instability. Scottish political thinkers played an influential role, not only in developing theories of resistance and revolution, but also in promoting the divine right of kings. ${ }^{5}$ Spottiswoode's change of mind is a good example of how people came to be persuaded of the value of royal absolutism.

In writing his History, Spottiswoode took care not to over-emphasize his own role in events, rather in the tradition of John Knox's History of the Reformation (though he was otherwise far from regarding this work as a model). This allowed him to draw a veil over his early presbyterianism. The History was written in the 1620 s at the request of King James, and it presented the royalist and episcopalian case with a calm dignity and restraint that, as Maurice Lee has persuasively argued, should not for a moment be mistaken for impartiality. ${ }^{6}$ This article will peer behind the veil. Not all the details can be recovered, but there are enough to make a coherent account-and, in the process, to shed further light on the History itself and its value for the events of the period. 
In Scottish ecclesiastical history there were few such politically eventful years as 1596, and the presbyterian movement was at the heart of the tumults. In March there was a renewed "covenant," adopted initially by the general assembly of the church and then in a number of synods, presbyteries, and kirk sessions. In the summer, the exiled Catholic earls of Huntly and Errol returned clandestinely to Scotland and sought rehabilitation. The presbyterians feared that they were working surreptitiously with the Octavians, eight reforming exchequer commissioners whose control of the purse-strings gave them political power, to restore Catholicism and bring in a Spanish army. A second Spanish armada, thought to be greater than that of 1588 , was mustering in 1596 . The presbyterians thus sought tough action against the Catholic earls, in particular demanding that they should be sent back into exile before any negotiations on their restoration could begin. The king was reluctant to concede this. The presbyterian campaign was co-ordinated by the commission of the general assembly, a standing committee of sixteen ministers.

Spottiswoode was first recorded as becoming publicly involved when the case of David Black hit the headlines. Black, minister of St Andrews, in October preached several allegedly seditious sermons against the king and Octavians. Challenged over this, he retorted that the king and privy council had no right to judge anything he said in the pulpit - that was reserved to his presbytery. This was adopted as an official church position; a formal "declinature" of the council's jurisdiction was drawn up by the commissioners of the general assembly on November 17, and rapidly circulated round the presbyteries gathering support. Spottiswoode was one of those who travelled round to gather ministers' signatures. Indeed he was the most active in this cause, according to another presbyterian activist, William Scot, minister of Cupar. Scot later had this to say about Spottiswoode:

Diligence was used in gathering subscriptions, so that in short space the hands of about four hunder were put to it. None so diligent as Spotswood, now Bishop of St Andrews, howbeit even then he revealled to the King all their counsells and proceedings, either by himself or by a courtier with whom he was familiar. He was the only suspected or known Judas among the ministery at that time. Ther were some others like Hazael, that understood not their own hollow hearts till time discovered them. ${ }^{7}$

As Alan MacDonald remarks of this, "The allegation that Spottiswoode was an agent provocateur smells strongly of a hindsight-ridden desire to portray him as having 
always been on the wrong side." 8 This is an accurate assessment, although we shall see that it is not the whole story, because not all presbyterians shared Scot's desire.

\section{II}

The confrontation between the king and the presbyterians escalated after the Black affair, and eventually erupted in an outright attempt at a coup d'état. Historians have tended to be beguiled by the vast smokescreen of self-exculpatory propaganda that the presbyterians emitted after the coup, and have usually called it a "riot" in Edinburgh on December 17, 1596. In reality this day was just the first of severalas Spottiswoode's account makes clear. ${ }^{9}$ The coup was carried out by an organized movement, which at short notice raised several hundred well-armed men and also brought a crowd onto the streets, demonstrating that it had wide popular support. The king was forced out of his capital on December 17, and on the next day the presbyterians invited a number of leading nobles to join them. If all had gone according to plan, the nobles would have constituted themselves a privy council in waiting. The king would have seen his support ebb away, and would have been forced to come to terms with the presbyterians in order to retain the ability to govern. However, the expected noble support failed to materialize, and it was the presbyterians themselves who suffered political defeat. Spottiswoode was one of the presbyterians.

Spottiswoode's History reveals much about his role in the attempted coup, at least as an eyewitness to the events. This may be surprising, since it is written with studied detachment and says nothing directly about what he himself did or witnessed. As one of the later writers on the subject, he had the opportunity to read and incorporate earlier accounts. ${ }^{10} \mathrm{He}$ would also have talked to many of those involved. Those who had witnessed events from a royalist perspective included, as well as the king himself, several of those with whom Spottiswoode worked daily in governing seventeenth-century Scotland, such as the earl of Mar, and two of the Octavians, Alexander Seton, earl of Dunfermline, and Thomas Hamilton, earl of Melrose. However, Spottiswoode witnessed the uprising from the presbyterian side, and his account must be read with this in mind. During the siege of the Edinburgh tolbooth, for example, the king and his supporters were inside and the presbyterians were outside; they had two different views of events.

Despite being basically a presbyterian's-eye view of the coup, Spottiswoode's History was quite different from retrospectively written presbyterian accounts. This was not just because he described the same events as they did but with disapproval rather than approval, though there were, of course, instances of this. Nor was it 
primarily because he did not have access to the largest presbyterian work, the history and supporting documents compiled by David Calderwood (another participant in the uprising), published only in 1678 and in abbreviated form. The most important differences came when Spottiswoode described events that the presbyterians distorted or omitted. Presbyterians had to present the events of December 17-19 as not having been treasonable. They thus pretended that they had not issued the call to arms, and omitted provocative episodes like the bond of December 18 that had been intended to serve as a manifesto for the coup. Spottiswoode was free to report these events accurately.

Spottiswoode was constrained, however, because he could not afford to write explicitly as an eyewitness. Others did so, like the Edinburgh burgess Patrick Anderson: "Many beheld this uncouth day and many yet beare record and quhairof I for ane was ane eye witness myselfe." the presbyterian crowd, even perhaps one of those who took up arms, rather than a neutral bystander-he based most of his account on the "Apology" of Robert Bruce, minister of Edinburgh, one of the leading presbyterians. However, he could write as he did because he was not a prominent figure, and knew that his account was not going to create problems for himself. Spottiswoode had to be more circumspect. He could not say "I saw the presbyterians carrying out these treasonable acts," because that would have raised the embarrassing question of what exactly he had been doing at the time. Still, it is possible to winnow his account and to identify likely eyewitness information.

The causes of the uprising were afterwards disputed. Royalist accounts usually said, accurately and straightforwardly, that the presbyterians had initiated a treasonable uprising. The presbyterians themselves gradually developed a complex alternative account whereby the call to arms had been issued by an agent of the gentlemen of the king's chamber in order to provoke a riot against the Octavians which could be blamed on the presbyterians. This was plausible because courtiers in the chamber were known to object to the Octavians' cost-cutting. The presbyterians' own role, they claimed, had been to pacify the confused crowd. This whole story was untrue, but politically necessary - they could otherwise have been convicted of treason.

Here Spottiswoode's account is of particular interest. The presbyterians had held a mass meeting in the Little Church of St Giles on the morning of the $17^{\text {th }}$, and the central disputed question was whether it was this meeting that had issued the call to arms. Spottiswoode made clear that it had, and that this was seditious: 


\begin{abstract}
"No course," said the Lord Lindsay, "but one; let us stay together that are here, and promise to take one part, and advertise our friends and the favourers of religion to come unto us; so it shall be either theirs or ours." Upon these speeches followed such a clamour and lifting up of hands, as none could hear what another spake. The sedition increasing, some cried to arm, others to bring out Haman (for whilst the lords were with the king, Mr Michael Cranston, minister of Cramond, had been reading to the people that story); others cried "The sword of the Lord and of Gideon."
\end{abstract}

This is almost certainly an eyewitness account, and as such is both credible and important. Calderwood corroborates the account of Cranston reading the story of Haman. ${ }^{13}$ Various sources including Anderson mention the Gideon slogan. Bruce's "Apology" corroborates the lifting up of hands. ${ }^{14}$ However, no other source mentions Lindsay initiating the call to arms, because no royalist witnessed it and no presbyterian was going to betray Lindsay by mentioning it. Lindsay took a public role on the street after the armed forces assembled, which was bad enough. Still, if royalists suspected that Lindsay had initiated the call to arms it would help to explain why he was a particular target of the royalist reaction. ${ }^{15}$ Conceivably, during the royalist reaction of early 1597, Spottiswoode acted as an informer against Lindsay or other presbyterians; if so this might be a partial truth behind William Scot's otherwise false charges that he had been an agent provocateur as early as November 1596. However, apart from Scot there is no direct evidence of this.

Spottiswoode is thus an important witness to the genuine seditiousness of the attempted coup of December 17-19. However, at one point his account did approach the presbyterians' self-exculpatory account of the alleged machinations of the king's chamber. He related a story of meddling by "some of the king's chamber" on December 16, the day before the uprising. It was they who informed the king that burgesses supporting the ministers of Edinburgh were making military preparations, and advised him to order their banishment from the town:

This they knew would be ill taken by the ministers; and to put them in a greater fear, they did advertise them by a counterfeit letter to look unto themselves, because Huntly had been with the king that night late, and caused that charge to be given. This letter sent to Mr Robert Bruce was by him communicated to Mr Walter Balcanquel, whose course it was to preach that morning. ${ }^{16}$

This story was attractive because it appeared to explain why Balcanquhal's sermon was so seditious. It may well bear some relationship to a story that surfaced in January 1597, of a gentleman sent in disguise from the chamber to the ministers on December 16 to warn them of the charge to banish their burgess supporters. ${ }^{17}$ The main problem with Spottiswoode's version is that the "counterfeit letter," if it 
had ever existed, would have been loudly cited by the presbyterians as soon as they needed an excuse. Yet neither they nor any other source mention such a letter. The letter seems to have been a subsequent misunderstanding or elaboration, either by Spottiswoode himself or by someone to whom he talked. It was not the only such elaboration; another evidently later account relied on an improbable "secret door" between the Little Church and the tolbooth. ${ }^{18}$

Where Spottiswoode's account is particularly valuable is in the events of December 18 and 19 in Edinburgh. The king fled from the town early on the $18^{\text {th }}$, leaving the presbyterians in control and needing to decide how to press their initiative. Other royalist accounts had little detail on this phase of the attempted coup - they were not there to see it. The presbyterians, for their part, said as little as they could on the subject. Spottiswoode, however, gave a circumstantial account. It began with the king on the $18^{\text {th }}$ having left a proclamation denouncing the uprising as seditious; "This proclamation, with the king his sudden departing, wrought a great alteration in the minds of the people." ${ }^{19}$ It is tempting to read this as the moment when the seeds of doubt about the presbyterian cause were sown in Spottiswoode's own mind. We shall see, however, that he remained at least outwardly radical for some time after the attempted coup.

Spottiswoode made clear that the proclamation did not, in fact, halt the coup's forward momentum. The burgh council "could not resolve what course to take" -

But the ministers persisting in their first resolution laboured to have the noblemen and barons remain together, and to send for others well affected in religion, who, as they thought, would join in the cause. A bond to this effect was drawn up, and subscribed by some few. The council of the town excused themselves, saying, "Their good will was known, and that they were not to leave their dwellings;" which made divers keep back their hands. ${ }^{20}$

This bond was clearly seditious, and was thus not mentioned by any later presbyterian account. Spottiswoode's account is corroborated in outline by the English ambassador, though Spottiswoode has more detail; the ambassador (writing on the $17^{\text {th }}$ ) mentioned only the plan for the bond. ${ }^{21}$ As a religious bond by a movement issuing a call to political action, it could be compared to the First Bond of the Lords of the Congregation (1557) or the National Covenant (1638).

Also on the $18^{\text {th }}$, the ministers wrote to Lord Hamilton asking him to lead the movement; this was corroborated by numerous sources, as the letter became public. Spottiswoode alone mentioned that they also wrote to Walter Scott of Buccleuch. ${ }^{22}$ In fact they seem to have written quite a few letters. ${ }^{23}$ The ministers also decided "that the rest of the ministers of the country should be convened as unto a General 
Assembly, and desired to bring with them the best affected gentlemen within their parishes." They had "a long deliberation, whether or not they should excommunicate the Lord President and Advocate" (Alexander Seton and Thomas Hamilton, two of the Octavians); they decided to leave this to the next general assembly of the church. ${ }^{24} \mathrm{~A}$ public fast was proclaimed, and sermons ordered in preparation. This led to another inflammatory episode:

A minister named Mr John Welch, making offer to supply the place in the High Church, was allowed to preach, who taking for his theme the epistle sent to the angel of the church of Ephesus, did rail pitifully against the king, saying, "He was possessed with a devil; that one devil being put out seven worse were entered in place; and that the subjects might lawfully rise, and take the sword out of his hand:" which he confirmed by the example of a father that falling in a frenzy might be taken by the children and servants of the family, and tied hand and foot from doing violence. A most execrable doctrine and directly repugnant to holy scriptures; which yet was taken by many of the hearers as a sound and free application. So ready are men to flatter themselves in wickedness, and even to justify impiety itself. ${ }^{25}$

Welsh, like Spottiswoode himself, was a junior minister with links to the early years of the Reformation-he was the son-in-law of John Knox. He was then minister of Kirkcudbright but would later, as minister of Ayr, become one of the leading presbyterian radicals of the early seventeenth century. The "epistle sent to the angel of the church of Ephesus" is Revelation 2:1-6, though this appears to bear no relationship to Welsh's sermon as Spottiswoode summarized it. It is conceivable that Spottiswoode's memory was at fault and that Welsh had actually preached on Ephesians 6, which discussed the relationships between children and parents and between masters and servants. ${ }^{26}$ Either Revelation 2 or Ephesians 6 would have been unusual choices for a political theorist, Protestant or Catholic, seeking biblical texts to justify rebellion. The principal Scottish writer on this topic, George Buchanan, had given extended discussions of only two texts: I Samuel 8 and the all-important Romans $13 .{ }^{27}$ Another possible source for Welsh's ideas might have been his father-in-law, Knox-perhaps a more natural influence for a minister than the secular-minded Buchanan; but Knox's political theory focused heavily on Romans 13, and in his political works he never cited either of Welsh's possible texts. ${ }^{28}$ As with Knox, however, Welsh's general approach was evidently, in Quentin Skinner's terms, "providentialist" rather than "scholastic." 29 He was a long way from the sober-minded rationalist that the mature Spottiswoode presented himself as being.

Spottiswoode's final piece of eyewitness information was: 
A rumour was then also dispersed throughout the town, that in the day of tumult the earl of Erroll did come to the Queensferry with five hundred horse, and was gone back upon report of the stir. This upon the Sunday took up a great part of the ministers' sermons, and was brought to justify the multitude's proceedings, as though they had been directed by a manifest providence to disappoint the wicked practices that were in hand. A manifest forgery it was, yet believed at the time by foolish and credulous people. ${ }^{30}$

Thus we see that even on the Sunday, December 19, the presbyterian movement was still attempting to rally military support by emphasizing the threat from the Catholic earls. Spottiswoode did not say exactly how or when the presbyterians abandoned their challenge to the king, but implied that it was when they realized that Lord Hamilton was not going to join them. He was particularly harsh on the letter to Hamilton, seeing correctly that it called for a military challenge to the king's government:

This letter, indited by Mr Robert Bruce, and subscribed by him and Mr Walter Balcanquel, was of all that yet had happened the worst, nor could it receive any good construction; for albeit in an apology afterwards set forth it was said to be penned only to please the nobleman, who was of an ambitious humour, yet put the case he had accepted, and taken upon him to be their head, as he was desired, who can tell what mischief might have ensued, and if it might not have turned to the wreck and ruin of many innocents? But faults follow one upon another, and when men have once passed bounds they run easily into error. ${ }^{31}$

Spottiswoode closed his account of the attempted coup with a moral:

Thus it proved true what Tacitus saith, "that all conspiracies of the subjects, if they succeed not, advance the sovereignty;" for by this tumult was the king's authority in matters ecclesiastical so far advanced, as he received little or no opposition thereafter. ${ }^{32}$

This is a good example of the lack of impartiality on which Professor Lee has commented, since historians agree that the king's episcopalian programme stirred up a great deal of opposition. But in the 1620 s, when episcopacy needed to be presented as securely established, it seemed the right thing for the archbishop to say. His quoting of Tacitus is also interesting. Tacitus was often used by writers interested in raison d'état and enhancing the ruler's power; he was also linked with contempt for the crowd and mass politics. ${ }^{33}$ 
Spottiswoode's account of the coup can be read as implying that he began to change his mind on December 17 itself, and this may indeed be when he began to have doubts. However, other evidence indicates that his formal break with the presbyterian movement came later-shortly after the collapse of the coup. The king reentered his capital on January 1, 1597, and began to re-establish his authority over the church and to punish ringleaders. In the end there would be no executions and most punishments were pecuniary, but it was not yet clear that this would be so. As Spottiswoode wrote:

The offers of the town, howbeit made in great submission, were not accepted, and counsel given by some noblemen to raze the town, and erect a pillar in place thereof, for a monument of the insolency committed, and the just punishment taken thereof. Others were more mild in their opinions; but for that time nothing was concluded. ${ }^{34}$

The ringleaders - including the four ministers of Edinburgh, who had fled to England at the end of December-were thus highly vulnerable and needed to do all they could to exonerate their conduct. Robert Bruce and the other exiled ministers wrote "Apologies." Their collective "Apology," written by Bruce, was dated January 4 . Calderwood wrote of it:

As their Apologie itself came into sindrie men's hands, so, among others, to Mr Johne Spotswod, now Bishop of St Andrewes. He appeared to be so fracke [i.e. active or bold] in their caus, that he would needs give it a sharper edge. ${ }^{35}$

Calderwood gave no further details, but we shall see that his account can be corroborated and expanded. The first thing that it tells us is that Calderwood, though he knew William Scot's work, did not stoop to Scot's "agent provocateur" slander. Calderwood clearly thought that Spottiswoode had been a genuine presbyterian, if misguidedly extreme in his views, whose backsliding from the cause required accurate reporting. His apparently cautious phrase, "appeared to be," might indicate that he thought Spottiswoode had been insincere in his radicalism, but it probably meant no more than it said: Spottiswoode was, as far as Calderwood knew, an extreme radical. Similarly he wrote of Michael Cranston, another participant in the uprising, that he was "then a verie fordward minister, but now key-cold."36

Corroboration for Calderwood, with important further detail, comes from the minutes of the presbytery of Edinburgh. On January 25, the "exercise" was made by two ministers, William Birnie and Spottiswoode, in which the first minister preached to the meeting and the second commented. The result was minuted: 
"The haill brether wer offended with the doctrine delyverit be the said Mr Johnn, [and] refussit to lat him mak the nixt day." 37 An official rebuke like this, against an established minister, was most unusual.

The presbytery of Edinburgh was still dominated by the radicals at this time. Their rebuke thus tells us that Spottiswoode had deviated from the official presbyterian line, and is likely to have prompted Calderwood's remark about giving the cause a sharper edge. Calderwood himself may well have witnessed, and participated in, Spottiswoode's discomfiture: he had not yet obtained a parish and his whereabouts are hard to trace, but he was mentioned as attending the presbytery of Edinburgh in May 1595 and November 1597, and probably attended at other times too. He had also probably participated in the attempted coup itself. ${ }^{38}$

Here we need to grasp the nature of the official presbyterian line in January 1597. According to Bruce's "Apology," the line ran as follows. The meeting in the Little Church had been lawful; it had not issued a call to arms; the call to arms had been a "false alarme;" the ministers had done their loyal best to pacify the confused crowd; and there would have been no problem had the Octavians not tried to incense the king against the ministers and to divert attention from the real issue, the Catholic threat. ${ }^{39}$

How could this have been given a "sharper edge?" The point of it was to display the ministers' peaceable loyalty. It did not claim that the uprising had been justified; it claimed that December's events had not been an uprising. The only "sharp" language in it was directed against the Octavians. Possibly Spottiswoode had simply expressed himself more forcibly against them, but it is hard to see how this would have attracted a formal rebuke. It is more likely that he had deviated from the official presbyterian line in a matter of substance rather than mere style.

The most likely way in which he could have done this would have been to argue that the uprising had been justified. This would have been a logical and even principled position for a presbyterian to take, but just then it was political dynamite. It jeopardized the credibility of the official presbyterian claim that no uprising had occurred. This would explain why it was important for the presbytery to rebuke Spottiswoode: he had to be silenced before such perilous views reached the king's ears and began to be used in treason trials. Spottiswoode himself was too junior to be likely to be charged with treason, but there were trials of several lairds and burgesses in late January and early February, and trials of Bruce and Balcanquhal were distinct possibilities. ${ }^{40}$

The presbytery minutes show that Birnie and Spottiswoode were preaching on Exodus 16:1-4, part of a series on this book. In this passage the Israelites "murmured 
against Moses and against Aaron in the wildernes" because they appeared to have escaped Egyptian slavery only to starve. ${ }^{4^{1}}$ This virtually invited a preacher to discuss the authority of the magistrate over the congregation-the central political issue of the day. It seems that Spottiswoode did so in a way that the mainstream presbyterians wished to disavow.

The dispute seems soon to have been patched up without becoming public. In late February, the presbytery of Edinburgh appointed three commissioners to a general assembly to be held at Perth to discuss the king's proposals for stabilizing the government of the church-and Spottiswoode was one of them. Another was Spottiswoode's father-in-law, David Lindsay, minister of Leith, who had a long presbyterian record and who had recently been one of the commissioners of the general assembly; the third was Patrick Galloway, minister to the king. ${ }^{42}$ The presbytery was thus making a gesture of trust in its wayward radical, Spottiswoode, presumably because it believed that he had learned his lesson or because it feared that he would do more damage if slighted further.

The gesture does not prove that the dispute had actually been resolved. Godly folk were generally reluctant to reveal internal disputes. ${ }^{43}$ It is perhaps for this reason that at this moment the sources falter. It would be particularly interesting to know what Spottiswoode said or did at the Perth general assembly, but there is no evidence on this. His long account of the assembly reads like the work of the eyewitness that he was, and it is of course favourable to the royalist and (as it shortly emerged) the episcopalian cause; but it says nothing of what he himself said or did at the time. ${ }^{44}$ He could have been converted to the royalist and episcopalian cause already, or he could have witnessed the events as a presbyterian (orthodox or extreme) and written them up later as an episcopalian. Unlike with the events of the coup, there were not two different sets of events to witness.

Spottiswoode had clearly renounced the presbyterian cause by May 1598, when he was an agent for the king in the latter's "tyrannous and imperious dealing" towards Robert Bruce (as Bruce saw it). The issue was whether imposition of hands was required for valid ordination as a minister; the presbyterians feared that if it became a requirement, the next step would be a requirement for imposition of hands by a bishop. 45

We can thus narrow down the period within which we have to seek, and explain, Spottiswoode's change of mind: it occurred between January 1597 and May 1598. We know that Spottiswoode began 1597 as an extreme presbyterian to whom his orthodox colleagues objected, and we also know that he moved over to become a royalist at some point within the next sixteen months. Here it is worth 
contemplating the position of an extreme presbyterian in more general terms. There is no direct evidence that Spottiswoode and his orthodox presbyterian colleagues were ever fully reconciled. In the absence of such evidence, the best that can be done is to follow the sequence of events. This sequence makes it implausible that such a reconciliation ever occurred. Is it likely that within this space he would have paused in his journey in order to espouse the orthodox presbyterian position, only to renounce it again almost at once? The possibility cannot be ruled out, of course, but there is no direct evidence for it, and it would be more straightforward to assume that no reconciliation occurred. In that case, once it became clear that it was not going to occur, Spottiswoode probably saw himself as having been rejected by the presbyterians whom he surely felt that he had served assiduously. How long it would have taken Spottiswoode to reach this conclusion is something on which one can only speculate, but it may be suggested that it would not have been long after January 1597, when the issues were still fresh.

Spottiswoode's motives for his change of mind were probably twofold. On the one hand, he was probably reacting in some way to his rejection by the orthodox presbyterians in January 1597. This was a circumstance that was unusual, perhaps even unique to him. He probably also had motives that were more widely shared. When he turned to the king, he no doubt reflected on the unplanned excesses of the coup which, thanks to royalist propaganda, looked a lot worse in retrospect than they had done at the time. That he changed his mind should not surprise us; many other ministers did the same. David Lindsay was among them; in 1600 this veteran presbyterian accepted a bishopric. ${ }^{46}$

By May 1599 Spottiswoode was still distanced from the presbyterians, but capable of surprising them with statements like "Lett us not seeke worldlie ease, with the losse of the libertie of Christ's kingdom," the result of which, according to Calderwood, was that "the brethrein tooke a good conceate of Mr Spotswod."47 This passage has been quoted as evidence that "Spottiswoode was still a staunch adherent of the presbyterian camp;" 48 however, it is implausible that Calderwood would have recorded "the brethrein" (the presbyterians) as forming a good opinion of one of their own members, and his point was surely that Spottiswoode was not one of them. Spottiswoode further demonstrated his separation from the presbyterians in March 1600 , when ecclesiastical representation in parliament was being debated, and he was officially chosen as a representative of the "king's side." 49 Calderwood recorded this without any suggestion that it manifested a change of mind on Spottiswoode's part, no doubt because the change of mind had occurred some years earlier and he felt that he had documented it sufficiently. 
Thereafter, Spottiswoode was mentioned exclusively with royalist associations. He achieved more political prominence when he was chosen as chaplain for the duke of Lennox's embassy to France in $1601 .^{50}$ William Scot's mention of "a courtier with whom he was familiar" (quoted above) might perhaps indicate that Spottiswoode was already associated with Lennox in 1596, but Scot's account is too coloured by hindsight to be accepted on this point without further corroboration. Spottiswoode's younger brother James, a junior administrator at the royal court, had participated in an embassy to Denmark and Germany in 1598, and might have been able to draw the future archbishop to the attention of the 1601 embassy's organizers. ${ }^{51}$ For Spottiswoode, at any rate, it was not far from that embassy to his 1603 archbishopric.

\section{IV}

This completes the account of Spottiswoode's conversion. However, it is worth glancing at his subsequent episcopalian career in order to see if it sheds any light on his early presbyterianism.

Spottiswoode was not a believer in a compromise polity embracing both episcopacy and presbytery. Margo Todd has recently argued that William Cowper, bishop of Galloway, held this belief. ${ }^{52}$ Spottiswoode, by contrast, wanted episcopacy to supersede presbytery. In 1610, at the time of the full restoration of diocesan episcopacy by the general assembly, he advised the king to "use the opportunitie to cutt tham [i.e. presbyteries] schort of thair power, and leave tham a bare name, quhiche for the present may please, but in a litle tym sal evanische." 53 However, when presbyteries refused to "evanische," he seems to have been willing to tolerate their continued existence with reduced powers, at least for the time being.

Spottiswoode had some sympathy for Cowper. In 1617 he displeased the king by signing Cowper's letter objecting to James's plan to have portraits of the apostles placed in the chapel royal.54 However, he also distanced himself from Cowper, in a passage that inadvertently admitted the presbyterians' success at winning hearts and minds:

An excellent and ready preacher he was, and a singular good man, but one that affected too much the applause of the popular. The good opinion of the people is to be desired, if it may be had lawfully; but when it cannot be obtained (as who is he that can please all men and at all times?) the testimony of a well-informed conscience should suffice. 55 
It seems to have been in matters to do with ceremonial worship, rather than church government, that Spottiswoode retained views with which the presbyterians might have sympathized. His reluctance to have the Five Articles of Perth introduced in 1618 is well known:

I would, if it had beene in my power, most willingly have declined the receiving of these Articles. Not that I did esteeme them either unlawfull or inconvenient, for I am so farre perswaded of the contrary as I can bee of any thing; but I foresaw the contradiction which would bee made, and the businesse we should fall into. Therefore, let no man deceive himselfe; these things proceede from his Majestie, and are his owne motions, not any others. ${ }^{56}$

Thereafter he was dutiful — neither enthusiastic nor obstructive-in enforcing the ceremonies enjoined by the Articles once the king had insisted on their passage. ${ }^{57}$ Royal authority was paramount.

How should Spottiswoode's change of mind be interpreted? Some ministers separated themselves from the presbyterian movement more in sorrow than in anger. This can be illustrated from the remarks of one who did not separate, Alexander Home, another participant in the coup. In 1609 he reproached the coup's leaders,

\footnotetext{
the pastoris of the Kirk of Edinburgh for the tyme, who raschelie behaved them selfis in that tumult at Edinburgh, the 17 day of December 1596, to the gryte greif and disgrace of the prince. Their zeill mycht weill haif bene fervent, but the forme wes informall and undecent; I speake it with regrett, for, being a present unlooker, I knaw quhat I saw and hard..$^{8}$
}

Although Home remained a presbyterian, his tone here was not too far from that of Spottiswoode's History. He wrote his account on his deathbed, which may explain both his unusual candour in admitting the presbyterians' subversiveness, and his prevailing tone of "regrett." Spottiswoode's account of the coup, too, was mostly calm, and presented the presbyterians as behaving with understandable if regrettable human weakness and misguided zeal. He used strong terms of condemnation only for John Welsh's sermon and the letter to Lord Hamilton.

It was, perhaps, the letter to Hamilton, together with the presbyterian bond also written on December 18, 1596, that convinced Spottiswoode of the misguided nature of the presbyterian movement. His comments show that he believed - at least in retrospect-that the coup had come close to success, but that the result would have been something like civil war: "the wreck and ruin of many innocents." Any 
reasonable person might have recoiled in horror from such a prospect. It is true that Spottiswoode did not recoil at once, since he was still maintaining a presbyterian position in January 1597. But if this article has correctly reconstructed his political trajectory, he had already separated from the presbyterian consensus at that point, maintaining a principled position of support for the 1596 coup and refusing to join the movement's more pragmatic leaders in disavowing it. In January 1597 he had thus been doing his best to maintain the ideological position that he had adopted before and during the coup. But he did so as an individual, not as a party man-hence his deviations from the presbyterian consensus, which the movement regarded as dangerous. Without a group of colleagues to reassure him and keep him in line, his doubts could grow until they produced a complete, but not necessarily unprincipled, change of mind.

\section{Notes}

1. For Spottiswoode generally see John Perry, "John Spottiswoode, Archbishop and Chancellor, as Churchman, Historian and Theologian” (University of Edinburgh $\mathrm{PhD}$ thesis, 1950), and A. S. Wayne Pearce, "John Spottiswoode, Jacobean Archbishop and Statesman" (University of Stirling PhD thesis, 1998).

2. John Spottiswoode, History of the Church of Scotland, 3 vols., eds. Mark Napier and Michael Russell (Edinburgh: Spottiswoode Society, 1847-51).

3. For the polity of the church in this period see David G. Mullan, Episcopacy in Scotland, 1560-1638 (Edinburgh: John Donald, 1986), James Kirk, Patterns of Reform: Continuity and Change in the Reformation Kirk (Edinburgh: T. \& T. Clark, 1989), chs. 5, 6, 9, and Alan R. MacDonald, The Jacobean Kirk, 1567-1625: Sovereignty, Liturgy and Polity (Aldershot: Ashgate, 1998). Kirk, ch. 11, discusses Spottiswoode as archbishop of Glasgow. For James vi's episcopalian programme see additionally Maurice Lee, Jr., "James Vi and the revival of episcopacy in Scotland, 1596-1600," Church History 43 (1974), pp. 50-64, reprinted in his The "Inevitable" Union, and Other Essays on Early Modern Scotland (East Linton: Tuckwell, 2003).

4. Pearce, pp. 31-32. The Second Book of Discipline (1578) was the founding document of the presbyterian system of church government. Perry, p. 11, makes only passing mention of Spottiswoode's early presbyterianism, but observes that his conversion to episcopacy entailed no "theological change," as he remained a Calvinist.

5. There is an extensive literature on this, but see in particular J. H. Burns, The True Law of Kingship: Concepts of Monarchy in Early-Modern Scotland (Oxford: Clarendon, 1996).

6. Maurice Lee, Jr., "Archbishop Spottiswoode as historian," Journal of British Studies, 13 (1973-74), pp. 138-50, reprinted in his The "Inevitable" Union. 
7. William Scot, An Apologetical Narration of the State and Government of the Kirk of Scotland since the Reformation, ed. David Laing (Edinburgh: Wodrow Society, 1846), p. 72. For Hazael see II Kings 8:8-15. Another presbyterian, Archibald Simson, gave a similar account of Spottiswoode: J. F. S. Gordon, Scotichronicon: comprising Bishop Keith's Catalogue of Scottish Bishops [...] , 2 vols. (Glasgow: Tweed, 1867), vol. 1, p. 367. However, a rumour does not become true by repetition. On the relationship between these two ministers and their writings, plus a third, David Calderwood, who will become more important shortly, see: Vaughan T. Wells, "Simson, Archibald (1564-1628)," Oxford Dictionary of National Biography, $2004[<\mathrm{http}: / /$ www. oxforddnb.com/view/article/25603>, accessed Oct. 17, 2006]; Vaughan T. Wells, "Calderwood, David (c.1575-1650)," Oxford Dictionary of National Biography, 2004 [<http://www.oxforddnb.com/view/article/4374>, accessed Oct. 17, 2006]; Alan R. MacDonald, "Scot, William (c.1558-1642)," Oxford Dictionary of National Biography, 2004 [<http://www.oxforddnb.com/view/article/69590>, accessed Oct. 17, 2006].

8. MacDonald, Jacobean Kirk, p. 71. Cf. Pearce, p. 34.

9. The events of December 1596, and the participants, are discussed respectively in Julian Goodare, "The attempted Scottish coup of 1596," and "The Scottish presbyterian movement in 1596," unpublished papers.

10. He had access to official documents. The minutes of the commissioners of the general assembly are the most likely source of his account of the commissioners' dealings with the Octavians, and of their statement that they would "obey God rather than man." National Library of Scotland, "Copie of the minute buik of the actis maid be the commissioneris of the generall assemblie," Wodrow Quarto, xx, no. 18, fos. 166v.-167r.; Spottiswoode, vol. 3, p. 18.

11. Edinburgh University Library, Patrick Anderson, "Historie of Scotland," Laing Mss, III.203, vol. ii, part II, fo. 261 r.

12. Spottiswoode, vol. 3, p. 29.

13. David Calderwood, History of the Kirk of Scotland, 8 vols., eds. Thomas Thomson and David Laing (Edinburgh: Wodrow Society, 1842-9), vol. 5, p. 512. For Haman see Esther 3-8; for Gideon see Judges 6-8 (slogan at 7:18).

14. Calderwood, vol. 5 , p. 562.

15. For the attack on him see National Archives of Scotland [hereafter NAs], treasurer's accounts, 1596-97, E21/71, fo. 10or.

16. Spottiswoode, vol. 3, p. 27.

17. Robert Bowes to Lord Burghley, Jan. 13, 1597, Calendar of State Papers relating to Scotland and Mary, Queen of Scots, 1547-1603, 13 vols., eds. Joseph Bain et al. (Edinburgh: HMSO, 1898-1969 [hereafter CSP Scot.]), vol. 12, pp. 425-6.

18. CSP Scot., vol. 12, p. 394.

19. Spottiswoode, vol. 3, p. 33 .

20. Spottiswoode, vol. 3, p. 33 .

21. Bowes to Sir Robert Cecil, Dec. 17, 1596, CSP Scot., vol. 12, p. 396.

22. Spottiswoode, vol. 3, p. 33 . 
23. The Warrender Papers, 2 vols., ed. Annie A. Cameron (Edinburgh: Scottish History Society, 1931-32), vol. 2, p. 303.

24. Spottiswoode, vol. 3, p. 33 .

25. Spottiswoode, vol. 3, pp. 33-34. A similar summary of the sermon, but omitting the text on which Welsh preached, is in Register of the Privy Council of Scotland, 37 vols., eds. J. H. Burton et al. (Edinburgh: HMSO, 1877- ), vol. 5, p. 359. Spottiswoode may have used this source.

26. Ultimately this question is probably unanswerable, but a fuller approach to an answer might be gained by investigating how far political sermons generally had political texts, or indeed texts relevant to their substance. Spottiswoode also noted the text on which Balcanquhal preached the day before-it was "out of the book of Canticles [i.e. the Song of Solomon], which was his ordinary at the time:" Spottiswoode, vol. 3, p. 27. This was not a political text because it was Balcanquhal's "ordinary," part of a regular series, on which he was forced to improvise. Welsh's sermon, by contrast, was deliberately planned. It might be mentioned that Welsh's "seven worse" devils were from Matthew 12:45 or Luke 11:26.

27. A Dialogue on the Law of Kingship among the Scots: a Critical Edition and Translation of George Buchanan's De Iure Regni apud Scotos Dialogus, Roger A. Mason and Martin S. Smith, ed. (Aldershot: Ashgate, 2004), pp. xlvii-xlviii, 109-25. This work was written in the late 1560 s and published in 1579.

28. Welsh was too young to have known Knox personally, but would presumably have heard a lot about him. For Knox’s political thought see Roger A. Mason, "Knox on rebellion," in his Kingship and the Commonweal: Political Thought in Renaissance and Reformation Scotland (East Linton: Tuckwell, 1998). For his political works see John Knox, On Rebellion, ed. Roger A. Mason (Cambridge: Cambridge University Press, 1994), where the one general reference to Revelation 2 (p. 32) turns out to refer to Revelation 2:20-3. Nor did Knox, at least in the key "1558 tracts," use Welsh's example of the "father [...] falling in a frenzy."

29. Quentin Skinner, The Foundations of Modern Political Thought, 2 vols. (Cambridge: Cambridge University Press, 1978), vol. 2, pp. 318-48.

3o. Spottiswoode, vol. 3, p. 34 .

31. Spottiswoode, vol. 3, pp. 34-35. Spottiswoode tactfully omitted the letter's third subscriber, Robert Rollock, the respected principal of the university of Edinburgh; Rollock, who rapidly made his peace with the king, was not regarded as a regular member of the presbyterian movement.

32. Spottiswoode, vol. 3, pp. 37-38.

33. Richard Tuck, Philosophy and Government, 1572-1651 (Cambridge: Cambridge University Press, 1993), pp. 39-45; David Allan, Philosophy and Politics in Later Stuart Scotland: Neo-Stoicism, Culture and Ideology in an Age of Crisis, 1540-169o (East Linton: Tuckwell, 2000), pp. 12-13.

34. Spottiswoode, vol. 3, p. 38 .

35. Calderwood, vol. 5, p. 560 . 
36. Calderwood, vol. 5, p. 512. Possibly the phrase "appeared to be" should be understood as "took part as being."

37. NAS, Edinburgh presbytery minutes, $1593-1600, \mathrm{CH} 2 / 121 / 2$, fo. $97 \mathrm{v}$. The phrase about "the nixt day" referred to the practice of having the commenting minister preach at the next meeting. I am grateful to Dr Alan R. MacDonald for a discussion of the presbytery minutes.

38. Alan R. MacDonald, "David Calderwood: the not so hidden years, 1590-1604," Scottish Historical Review, 74 (1995), pp. 70-71.

39. Calderwood, vol. 5, pp. 560-74.

40. Criminal Trials in Scotland, 1488-1624, 3 vols., ed. Robert Pitcairn (Edinburgh: Bannatyne Club, 1833), vol. 2, part I, pp. 3-14, 29-34; NAS, draft indictment of unnamed person, JC27/39.

41. The Geneva Bible added in the margin: "So hard a thing it is to the flesh not to murmure against God, when the belly is pinched."

42. CSP Scot., vol. 12, p. 476. This commission raises an issue of identification, because there was another minister called John Spottiswoode. Throughout the 1590 o he was minister of Mordington, in the presbytery of Chirnside. Pearce, p. 27, regards the commission of February 1597 as being to this second Spottiswoode, but this is based on a misunderstanding. Pearce believes that in 1597 the second Spottiswoode was minister of Cramond, in the presbytery of Edinburgh; in fact he had been minister there only briefly in 1580-81. For the second Spottiswoode's career see Hew Scott (ed.), Fasti Ecclesiae Scoticanae, 7 vols. (2 ${ }^{\text {nd }}$ edn., Edinburgh: Oliver \& Boyd, 1915-), vol. 1, pp. 10, 356; vol. 2, pp. 24, 57, 83. Our Spottiswoode was not a member of the presbytery of Edinburgh either-his presbytery was Linlithgow. But he was much nearer to Edinburgh than the second Spottiswoode (Mordington was adjacent to the Anglo-Scottish border at Berwick), his presbytery was in the same synod as Edinburgh (Lothian and Tweeddale; Chirnside, by contrast, was in the synod of Merse and Teviotdale), and he is known from other sources to have been active in ecclesiastical politics in Edinburgh in 1596-97, while the second Spottiswoode was an obscure figure. The Spottiswoode to whom the presbytery of Edinburgh gave a commission in February 1597 was surely the same as the Spottiswoode with whom it was involved in January 1597, and the Spottiswoode of January 1597 was almost certainly, from Calderwood's evidence, the future archbishop. The presbytery of Edinburgh may have treated him as one of its members because the exile of the burgh's own ministers had left the presbytery short-staffed.

43. For an English case-study demonstrating this in detail see Peter Lake and David R. Como, “'Orthodoxy' and its discontents: dispute settlement and the production of 'consensus' in the London (Puritan) 'underground'," Journal of British Studies, 39 (2000), pp. 34-70. On godly networks in Scotland see David G. Mullan, Scottish Puritanism, 1590-1638 (Oxford: Oxford University Press, 2000), ch. 1.

44. Spottiswoode, vol. 3 , pp. 40-55.

45. Calderwood, vol. 5, pp. 720-23. 
46. James Kirk, "Lindsay, David (1531-1613)," Oxford Dictionary of National Biography, 2004 [<http://www.oxforddnb.com/view/article/16695>, accessed Oct. 18, 2006]. The "conjectur[al]" suggestion has been made that it was Lindsay who persuaded Spottiswoode to change sides: A. S. Wayne Pearce, "Spottiswoode, John (1565-1639)", Oxford Dictionary of National Biography, 2004 [<http://www.oxforddnb.com/ view/article/26167>, accessed Nov. 12, 2007]. There is no actual evidence for this, and the evidence presented in the present article indicates that Spottiswoode was independent-minded, but it is of course inherently probable that Spottiswoode, Lindsay, and other ministers discussed the issue. The fact that the king had bishoprics to offer to his supporters may have been an additional motive, but it seems unnecessary to charge Spottiswoode with unprincipled careerism if-as is argued in this article-there are principled explanations available.

47. Calderwood, vol. 5, p. 738.

48. Pearce, p. 38 .

49. Calderwood, vol. 6, p. 2. Cf. Alan R. MacDonald, "Ecclesiastical representation in parliament in post-Reformation Scotland: the two kingdoms theory in practice," Journal of Ecclesiastical History, 50 (1999), pp. 38-61. Pearce, who omits the evidence from 1597 and 1598 cited above, regards the episode of March 1600 as the first evidence of Spottiswoode's royalism: Pearce, p. 39.

50. Helen G. Stafford, James vi of Scotland and the Throne of England (New York: American Historical Association, 1940), pp. 230, 259-6o; Spottiswoode, vol. 3, p. 100.

51. Pearce, pp. 16-17. Spottiswoode's appointment in May 1601 as one of three ministers to the prince's household may also have drawn attention to him: Booke of the Universall Kirk: Acts and Proceedings of the General Assembly of the Kirk of Scotland, 3 vols., ed. Thomas Thomson (Edinburgh: Bannatyne Club, 1839-45), vol. 3, p. 969.

52. Margo Todd, "Bishops in the kirk: William Cowper of Galloway and the puritan episcopacy of Scotland," Scottish Journal of Theology, 57 (2004), pp. 300-12.

53. Spottiswoode to James, Mar. 12, 1610, Original Letters Relating to the Ecclesiastical Affairs of Scotland, 2 vols., ed. David Laing (Edinburgh: Bannatyne Club, 1851), vol. 1, p. 235 .

54. Spottiswoode, vol. 3, p. 237; cf. Pearce, pp. 277-78.

55. Spottiswoode, vol. 3 , p. 258.

56. Spottiswoode's sermon to the Perth general assembly, Aug. 25, 1618, Miscellany of the Spottiswoode Society, vol. 1 (Edinburgh, 1844), p. 83.

57. There is an extensive literature on the implementation of the Five Articles of Perth. See in particular MacDonald, Jacobean Kirk, pp. 167-70; David Stevenson, "Conventicles in the kirk, 1619-1637: the emergence of a radical party," Records of the Scottish Church History Society, 18 (1972-74), pp. 99-114; P. H. R. Mackay, "The reception given to the five articles of Perth," Records of the Scottish Church History Society, 19 (1977), pp. 185-201; Laura A. M. Stewart, “'Brothers in treuth:' propaganda, public opinion and the Perth Articles debate in Scotland," in Ralph Houlbrooke (ed.), James vi and I: Ideas, Authority, and Government (Aldershot: Ashgate, 2006), pp. 151-68; 
Laura A. M. Stewart, "The political repercussions of the Five Articles of Perth: a reassessment of James VI and I's religious policies in Scotland," Sixteenth Century Journal 38 (2007), pp. 1013-36. For Spottiswoode's role see Pearce, chs. 8-9, and Perry, pp. $25-31,183-85$. For the wider context see Alan R. MacDonald, "James VI and I, the church of Scotland, and British ecclesiastical convergence," Historical Journal, 48 (2005), pp. 885-903.

58. Alexander Home, "Ane afold admonition to the ministerie of Scotland, 1609," Miscellany of the Wodrow Society, vol. 1, ed. David Laing (Edinburgh, 1844), p. 585. 